\title{
The Concept of Authentic and Inauthentic Existence in the Philosophy of Martin Heidegger: The 'Quarrel' of Communitarians and Libertarians
}

\author{
Eugene Anowai ${ }^{1} \&$ Stephen Chukwujekwu $^{1}$ \\ ${ }^{1}$ Department of Philosophy, Odumegwu Ojukwu University, Igbariam, Anambra State, Nigeria. \\ Correspondence: Eugene Anowai, Department of Philosophy, Odumegwu Ojukwu University, Igbariam, Anambra State, \\ Nigeria. E-mail: chukwueloka@yahoo.co.uk
}

\author{
Received: December 6, 2018 Accepted: March 13, 2019 Online Published: March 14, 2019 \\ doi:10.5539/res.v11n2p1 \\ URL: https://doi.org/10.5539/res.v11n2p1
}

\begin{abstract}
The everyday use of the term 'authenticity' tends to mean 'real', 'genuine' or 'true', and 'inauthentic' as 'fake', 'fraud' or 'impostor'. These terms are more value-judgments with something inherently better than 'inauthentic'. The idea of authentic wishes to liberate the individuals from the constraints of their own socio-historical limitations; and to establish being as limitless potential, where we are free to be whatever we want,unconstrained by the values of instrumental or calculative thought prized by social exigencies and ideologies. It means that we have to use our potentialities as free Beings to overcome unfavourable circumstances,fight against, or protest against the ugly situation, but as 'authentic-being, we at the same time 'inherit and choose' our own possibilities. So in transcending our socio-historical condition, our aim should be to be free from constraints, free from 'the-they' and be true to who we are.This paper holds brief for the Libertariansand liberals and supports the view that individual choice is important. But then, the community is indispensable in defining and shaping individuals in the light of communitarians.
\end{abstract}

Keywords: authentic, inauthentic, constraint, choice, freedom, social exigencies, communitarianism and libertarianism

\section{Introduction}

Husserl traced the element of the world in their historical and psychological reality to the final state of "ideal essences", which in turn should give us the explanation of historical and material reality. For Heidegger on the contrary, the existent reality should give us an understanding of the essence of reality. Thus every metaphysical investigation must start from reality as it is in our experience. That is, from existent reality and seeks to determine what it is in its finiteness, that is in its existence and its temporal possibilities for developing different forms of its own existence. Therefore, the initial problem of philosophy must be the following: why am I here, rather than not existing at all? If I am able to determine the essence of existent being, then I know what being is. In his attempt to inquire into the nature of existence, he proposes what he calls the fundamental ontology and in trying to analyse it, he came up with the concept of authentic and inauthentic existence.

\section{Fundamental Ontology}

Heidegger's ultimate goal was to provide an adequate answer to the question: what is being? He therefore sets out to restore being to its rightful status as the root of reality. In the course of answering this perennial question, or the meaning of being, he provides us with an existential analysis of human existence. Hence, to inquire into the meaning of being, he takes up the task of a fundamental ontology. To disassociate his philosophy from the previous treatments of the topic, he uses the term Dasein as a technical term to stand for being. The German word Dasein literally means 'being there'. We are characterised as 'being there' in the sense that we are always situated or related to the world in a certain way. Dasein cannot be defined as a set of fixed properties instead we all are characterized as a set of possibilities and we have the responsibility of choosing what we will. We are unique in the sense that we are the only kind of entity in the world able to raise question about what it means to exist.

Heidegger is in essence trying to tell us that in order to understand the meaning of Being, we have to explore the basic structure of Dasein, and in this way, the meaning of being would be disclosed and uncovered to us. This task of laying bare the constitution of Dasein is what Heidegger means by fundamental ontology. So fundamental ontology - the sole successful candidate for the investigation of Being is Dasein. Finally, the question of the meaning of being has found focus of inquiry in the Being of man-Dasein. Heidegger's choice of "man" as a get-way to the inquiry into the meaning of being (sein) is based on the fact that he alone occupied a privileged position with regard to the question of being. Thus, man is the only being that can interrogate itself about his own being and investigate into the meaning of other beings. In other words, man is transparent in his own being and possesses pre-ontological understanding of other beings. As 
Lawhead (2002) noted, "Heidegger begins his analysis of Dasein at the most generic level of human existence" (p. 536), the realm of average everyday experience. This is the world in which we live prior to any philosophical speculation. "We can move from our near immersion in the world to a full ontological appreciation of what is on the ground and meaning of all things. In doing this, Heidegger introduces a complex set of interrelated existential that characterises our mode of existence, like, Being-in-the world, facticity, Being-ahead, and falleness" (p. 536) For our purpose we need to discuss Being-in-the-world.

\section{Being-in-the-World-in der Welt Sein}

Heidegger "rejected the philosophical tradition which tended to separate the knowing subject and the object of knowing and treat them as different entities" ( $p .356$ ) Descartes we know for example in his methodical doubt identified himself with consciousness and worried about how he could know that this consciousness was related to an external world. On his side, Husserl "bracketed the world in order to focus on the nature of pure consciousness". However, Heidegger considers this as the first step to scepticism, for once we assume that consciousness can be meaningfully considered in isolation from the world, they become difficult to reunite. In modern philosophy, this is sometimes referred to as "the problem of subject-object dichotomy. But Heidegger sweeps aside the whole problem with a single fundamental concept. Hence he refers to Dasein as being-in-the-world. The hyphens in this phrase indicate that Dasein cannot be separated from the world, for our existence is a world-embedded existence. Hence being-in-the-world is a fundamental structure of human existence.

As noted above, Heidegger is concerned with how we can understand what being in the world means and our experience of it. He finds out that the first phenomenological fact of existence is that we are always already out there in the world. $\mathrm{He}$ thus describes our human being (as opposed to the being of an inanimate object or non-human animal) as Dasein. Thus, to describe human being as Dasein is an attempt to leave behind philosophical notions of the individual as subject, and more broadly, the subject-object duality of the individual and the world, that is, interior consciousness juxtaposed against an objective world outside of it. Rather, for Heidegger we are out there embedded in the world, engaged with tools and objects of our experience. Heidegger (1962) says, "Dasein finds 'itself' proximally in what it does, uses, expects, avoids - in those things environmentally ready-to-hand with which it is proximally concerned "(p.155)

Having analysed our Being-in-the-world within the mode of everydayness, he now considers the possible ways in which we can relate to it. Let us summarise it thus:

1. Dasein is already-in -a-world. We find ourselves "thrown" into a particular situation. This refers to our facticity (this has to do with the state of the mind as it anticipates the rather indefinite time of death) the unique deposit of given facts that makes up each person's past.

2. Dasein is being-long-with-the-world. We engage in things that are ready-to-hand within the world as well as with other human beings. However, we tend to become absorbed into our situation; losing ourselves in the world of impersonal, anonymous "they". We experience this fallenness within our present situation.

3. Dasein is Being-ahead-of-itself: our past and present do not sum up what we are, for we are a field of possibilities that offer us choices in each moment of our existence. "This existential structure of possibility includes the fact that our over orientation towards the future provides part of the structure of who we are in the present"(Lawhead,p.540) This analysis indicates the temporality of Dasein. I cannot understand my experience apart from what I have been, what I am and what I will be

As human beings, we make choices because we care about our existence. Unlike a busy ant following the dictates of its biological programming, we are beings who are structured by our possibilities and whose existence necessarily involves making choices.

There are two ways of choosing: Dasein always understand itself in terms of its existence, in terms of a possibility of itself. To be itself or not itself Dasein has either chosen these possibilities itself, or got itself into them or grown up in them, Dasein is the only being that has freedom of choice between alternatives - to stand out or not to stand out. He alone has the capacity to choose or decide. Hence, comes the issue of authentic or inauthentic existence.Heidegger distinguishes two ways of living: the one inferior, called inauthentic; the other superior, called the authentic.

\section{Inauthentic Existence of Dasein}

Inauthenticity comes from the German word "uneigentlichkeit" meaning "to disown". This is related to the fact that "man's being" is thrown into the world where there are other existents. "If I consider my choice as pre-given and just accept the situation I have drifted into or grown up with, as though I had no possibilities I will live inauthentically." (Lawhead,p.540) Again, my being (Dasein) should be living inauthentically where it is submerged in a kind of anonymous mass by routine manner of life in which his possibilities are taken over and dictated to it by social pressures. Sure man is thrown into the world where there are other existents, but in this situation, he is expected to take an initiative 
towards discovering the meaning of his own existence. And failure to do this, he is absorbed in an instrumental world that makes him abandon his "I-hood"existence in uncritical participation in the worldas it is.

There is everywhere the desire to conquer nature, but in the process, the value of the conqueror himself who is man is destroyed and his very existence threatened. This is because man advances technologically every day. He is so preoccupied that he is worried about technologies and not about himself. That is how he loses himself in things. To gain the world amounts to becoming lost in it and in this way, he is engulfed by the world of things.

The preoccupation with things is coupled with solitude for the other existents. Dasein is "existence-with"(mitdasein). Dasein's relationship with co-Dasein, otherwise called being-with-others (mitsein)is inescapable. But sometimes it takes degenerated forms and swings into inauthentic existence, which set in where there is unregulated empathy. Paradoxical as it seems is thus asserted by King: care for....

"Jumps in" for the other... It takes the care off the other, usually by taking care of his place by stepping in his stand so that the other takes over ready-made what he should have taken care for himself. In such caring for, the other can easily become dependent and dominated in such unobtrusive fusion that it may often pass unnoticed by him (King, 1966, p.107).

This type of interdependence is an aberration, the genuine human and personal existence is suppressed. It gives room for depersonalisation and dehumanisation. In this case, man surrenders to the "they-self" at the expense of his selfhood, he engages in banal existence by being absorbed or immersed in the crowd consciousness. His thinking and power of expression move on the level of common place and naive interpretations. There is a mass existence that insists on the blind acceptance of norms and the community spirit. It is "DasMan" (the "they self") that is available. In Heidegger's words as Crites puts it "'inevitable and continuously, the forward driving "I" is sacrificed to the persistent and pressing "they". And to the question "who is human being?" we must answer, "the indifferent and anonymous crowd "Das Mann".

Das Mann is not easy to translate, since normally man is a pronoun in German and takes no article. The phrase is usually translated as "the they", although the pronoun man can be variously translated as "people", "others", "they", "public opinion", "one", and even "we"("What will people think?" "They say that...." "One doesn't expect...." "We don't do that"). Das man means other people in the abstract, generic sense - not a set of individuals, not as an organisation or body, but generally as postulated carriers of cultural mores, expectations, or norms. Heidegger says it means "the others" but "not definite Other". It "is not this one, not that one, not oneself, not some people, and not the sum of them all. Das man thus is a sort of horizontal version of... "they, out there" or "they, all around me".

Heidegger maintains that in our ordinary, day-to-day living we conduct ourselves with reference to this projected, generic "they" referring to it ascribing to it responsibility for what we do, and seeking fulfilment through it. This way of living, Heidegger calls our 'they-self'. It is not, however, our real or authentic self. The latter can emerge only after the individual isolates himself from the others and questions conventions and habitual assumptions by philosophical inquiry.

For Nietzsche, this conventional existence is expressed in the "herd" while Kierkegaard, the father of existentialism finds it in the "crowd" which he abhors and so, "a crowd in its very concept is the untruth by reason of the fact that it renders the individual completely impertinent and irresponsible or at least weakens his sense of responsibility by reducing it to fraction. Kierkegaard (1962) describes the modern society as a network of relations in which individuals are leveled into an abstract phantom known as "the public" (p.59).

Kierkegaardemphasized the individual over the "numeric masses". He maintained that God has no relation to mankind as a whole. The individual is more important than the Universal (the law, morality). When Abraham was commanded by God to kill his son Isaac, the Absolute (God) was contravening the Universal. Kierkegaard did not prescribe lawlessness, much less anarchy - which is rule by the numeric masses. Rather, each individual must come into a relationship with the Absolute (the religious stage) whereby the ethical stage can be properly established.

The modern public in contrast to ancient and medieval communities is a creation of the press, which is the only instrument capable of holding together the mass of unreal individuals "who never are and never can be united in an actual situation or organization" (Kierkegaard,p.60). In this sense, society has become a realization of abstract thought, held together by an artificial and all-pervasive medium speaking for everyone and for no one.

This means that existence alienates man. The individual private ego and its genuine intentions, endeavours and responsibility give way for anonymous and faceless public ego.

Inauthentic existence is also seen in idle talk. Dasein takes whatever is said without a second thought. There is also curiosity when Dasein preoccupies itself with the worries or attractions of this world. In temporality, we can also observe an inauthentic existence too. This is found in the way people stick to the past. They spend the whole of their life brooding over their past mistakes without any consideration of the future. 


\section{Authentic Existence of Dasein}

Authentic existence comes from the German "Eigentlichkeit,"which is the equivalent of the English word authenticity and means real or proper - "owned existence". Authentic existence does not deny or disown the attitude of everyday existence in toto. Without everydayness, self-fulfilment is a mirage; hence, man must exist in the world and with others too. 'Man is inextricably a being-in-the-world', existing in unavoidable contingency with all that surrounds him. Authenticity enables man to see his everyday life in an entirely new perspective. Heidegger sees the authentic existence of man as depending on the mineness of his action. Mineness rejects passivity which characterises ontic existence. Minenness is inseparable from ontological existence. It expresses "I-hood" and from it originates responsibility. Mineness gives one personal identity. The "I" replaces the anonymous "they," which characterised group consciousness; thus, authentic existence proclaims the practical uniqueness of the individual. Here, man recognises and affirms responsibility for all his actions. Hence, Macquarrie in bringing I-hood and mine-ness into parity said, "an existent is not just an "it", existent says "I" ...mineness is unique and distinct from the existence of everyone else. I am just a specimen of a class. I am I..." (Macquarrie 1965, pp. 72-72). and individual existence is distinct by its possession of "I-hood". Non-Dasein does not have mineness. For the fact that Dasein is an existent characterised by everydayness, it is bound to stray and that is why Heidegger said that fallenness belongs to Dasein's state of being. D. E. Roberts(1959) in a bid to show that there is need for individuals to come out of this collective mass, observed that, "the individual reaches true selfhood only by rising out of it, though naturally, he can never completely separate himself from it"(p. 151).

On the whole, for Heidegger, being authentic does not require some exceptional effort or discipline, like meditation. Rather, it entails a kind of shift in attention and engagement, a reclaiming of oneself, from the way we typically fall into our everyday ways of being. It is about how we approach the world in our daily activities. Dasein inevitably moves between our day-by-day enmeshment with the they and a seizing upon glimpses of our truer, uniquely individual possibilities for existence. The challenge is to bring ourselves back from our lostness in the they to retrieve ourselves so that we can become our authentic selves.

This finding of itself by Dasein, Heidegger says, is a response to the voice or call of conscience. He does not mean here anything like a moral imperative to do the right thing according to an external law, but rather a clear and focused listening to and heeding of one's unique capabilities and potential. In doing so Dasein authentically understands itself and is able to act in the world accordingly. This type of action for Heidegger would be authentic and ethical action in the sense of its indication that one is being true to oneself, hence the language of conscience. For instance, in career development work in college and university, counsellors offer guidance to students so they can better understand themselves in terms of their aptitudes, interests, and abilities. They encourage them to discover their true "vocation" (their calling), the type of work that would suit them and be their own. This calling is precisely what Heidegger is talking about. Heidegger refers to this unique and special moment in Dasein's existence, when there is clarity about the self, as the moment of vision. In conjunction with this moment of clear vision, Heidegger uses the concept of resoluteness to capture what it means for Dasein to heed this call of conscience and act accordingly and consistently, over time. He says that resoluteness or resolve means "letting oneself be summoned out of one's lostness in the 'they' and carving out one's unique and authentic place in and approach to the world, doing one's work with this special intent and self knowledge(Heidegger, p.345).

\section{Authentic (Eigentlichkeit) and Inauthentiicn (Uneigentlichkeit) Existence}

The authentic existence consists in an analysis of self. Although distinct from inauthentic existence, they have some common characteristics.

1. Actual participation in the world; this means that an existent being has a relationship to surrounding objects that he uses as instruments of existence

2. Existence in a determined situation; this means that every situation is essentially individuated, limited and presents one of the infinite number of possible ways of realising existence. In this case, existent is in a state of inferiority, of privation, of radical poverty as regards plenitude of being. On the other hand, the inauthentic life is distinct from the authentic life in many ways. The inauthentic life is characterised by its banality. The subject of such a life is not the individual, but an anonymous and featureless public ego ("das Mann"), the one-like-many, shirking personal responsibility and taking cues from the convention of the masses. The result is self-estrangement of human existence, which leads eventually to the blotting out of its possibilities and its disintegration in the relevancy of everyday life (Heidegger, pp.479-480).

Authentic existence is something decidedly different from everyday life. Living authentically means that in the face of throwness, Dasein recognises that he is the one who has to make choices from the realm of his potentialities. Thus, "authenticity is taking hold of myself in my own way". It expresses I-hood, gives one personal identity. The "I" replaces the anonymous "they" which characterises group consciousness. Authentic existence proclaims the practical uniqueness of the individual. Dasein becomes responsible for his actions. Therefore, to live authentically means "to exist"; this in turn 
means to stand out - from the Latin "ex-stare"; that is, to be outside the anonymous mass, to emerge from the world in which we find ourselves, and to accept our situation with all limitations. To exist means both to stand apart (to withdraw) and to stand out (to be offered as a target for the fullness of being).

All said and done, the crucial question is, can the so called authentic being do it alone going by the nature of man as social and political animal?

\section{Man as a Social and Political Animal}

That man is much more a political animal than any kind of bee or any herd animal is clear. For, as we assert, nature does nothing in vain, and man alone among the animals has speech. Speech serves to reveal the advantageous and the harmful and hence also the just and unjust. For it is peculiar to man as compared to the other animals that he alone has a perception of good and bad and just and unjust and other things of this sort; and partnership in these things is what makes a household and a city (1253a8).

Social animal, like bees and herd animals, human beings live together in groups. Unlike bees or herd animals, humans have the capacity for speech - or, in the Greek, logos. As we have seen, logos means not only speech but also reason. Here the linkage between speech and reason is clear: the purpose of speech, a purpose assigned to men by nature, is to reveal what is advantageous and harmful, and by doing so to reveal what is good and bad, just and unjust. This knowledge makes it possible for human beings to live together, and at the same time makes it possible for us to pursue justice as part of the virtuous lives we are meant to live. Other animals living in groups, such as bees, goats, and cows, do not have the ability to speak or to reason as Aristotle uses those terms. Of course, they do not need this ability. They are able to live together without determining what is just and unjust or creating laws to enforce justice among themselves. However, Human beings, for better or worse, cannot do this. Heidegger's stress on man's individualisation of himself from associations with others as a basic requisite for authenticity is prone to encourage disregard for community spirit., thus, implying social cohesion. Man cannot be without others and this made Aristotle and J. S Mill advocate for man's observance of his nature as an "ens socialis" - social being. This is why we have human associations, societies, organisations and so forth..

From Heidegger we were allowed to understand that authenticity goes with 'mineness' of choice. Man should make his choice on purely individualistic and relativistic bases. He should not conform to laid down rules and regulations that characterise mass-existence (inauthenticity). In this, Heidegger confuses us as to what would be the criteria for authentic and inauthentic existence. It implies that everybody should conform to what he or she chooses. Then, there would be a lawless society where chaos, anarchy, impunity and doom will surely erupt and triumph.

Although nature brings us together but according to Aristotle, we are by nature political animals - nature alone does not give us all of what we need to live together: "There is in everyone by nature an impulse toward this sort of partnership. And yet the one who first constituted [a city] is responsible for the greatest of goods" [1253a29]. We must figure out how to live together for ourselves through the use of reason and speech, discovering justice and creating laws that make it possible for human community to survive and for the individuals in it to live virtuous lives. And in discovering and living according to the right laws, acting with justice and exercising the virtues that allow human society to function, we make possible not only the success of the political community but also the flourishing of our own individual virtue and happiness. Without the city and its justice, human beings are the worst of animals, just as we are the best when we are completed by the right kind of life in the city. And it is the pursuit of virtue rather than the pursuit of wealth or security or safety or military strength that is the most important element of a city: "The political partnership must be regarded, therefore, as being for the sake of noble actions, not for the sake of living together" (1281a1).

Although in some ways we have clearly moved beyond Aristotle's thought (for example, his belief in the inferiority of women and his approval of slavery in at least some circumstances), there remains much in his philosophy that is valuable today.

In particular, his views on the connection between the well-being of the political community and that of the citizens who make it up, his belief that citizens must actively participate in politics if they are to be happy and virtuous, and his analysis of what causes and prevents revolution within political communities have been a source of inspiration for many contemporary theorists, especially those unhappy with the liberal political philosophy promoted by thinkers such as John Locke and John Stuart Mill.

The only condition that goes on directly between men without the intermediary of things or matter corresponds to the human condition of plurality, to the fact that men, not Man, live on the earth and inhabit the world. While all aspects of the human condition are somehow related to politics, this plurality is specifically the condition...of all political life (Arendt, 1958, p. 7).

\section{Heidegger, Communitarianism and Libertarianism}

Heidegger's emphasis on man's individualism and distance from association with others as a basic requisite for 
authenticity is prone to disregard community spirit and social cohesion that is very much required in our contemporary globalised world. This is a disregard to the philosophy of communitarianism which began in the late $20^{\text {th }}$ century and emphasizes the need to balance individual rights and interests with that of the community as a whole. That is to say, that the autonomous selves are shaped by the culture and values of the community. It also emphasizes the role of the community in defining and shaping individuals. The communitarians believe in the value of community; for them, values and beliefs exist in public space, in which debate takes place.

In general, communitarians value tradition, ethnic, regional or national identity and the common culture that comes from religion or shared moral values. They emphasize the importance of belonging to a certain community and sharing in its traditions, values and culture (Anowai 2014, p.213). During the 17th century, the exponents of the school of natural law, especially Hugo Grotius, surnamed the father of natural law science, showed that "man is a sociable being by its nature, who wishes to live peacefully with its fellows, able to determine by himself on what is useful or harmful for society."(Corneliu2005, p.20)

On the other hand, the term Libertarianism is used to represent political philosophies which place individual liberty at top priority and so seek to minimize or even abolish the state"(Murry 1977). In a metaphysical or philosophical sense it was used by late Enlightenment free-thinkers to refer to "those who believed in free will as opposed to determinism. That is to say that the libertarians believe in individual liberty and personal responsibility on all issues at all times" (Boaz, 1998, p. 22-25).

According to the Internet Encyclopedia of Philosophy: Libertarians are committed to the belief that individuals, and not states or group of any kind, are both ontologically and normatively primary; that individuals have rights against certain kinds of forcible interference on the part of others. Again, that the liberty, understood as non interference, is the only thing that can be legitimately demanded of others as a matter of legal or political right; that robust property rights and the economic liberty that follows from their consistent recognition are of central importance in respecting individual liberty. Moreover, that social order is not at odds with but develops out of individual liberty; that the only proper use of coercion is defensive or to ratify an error. That governments are bound by essentially the same moral principles as individuals; and that most existing and historical governments have acted improperly insofar as they have utilized coercion for plunder, aggression, redistribution, and other purposes beyond the protection of individual liberty"(Boaz 1998, p' 22-25). Generally, libertarians focus on the right of the individual to act in accordance with the individual's own subjective values. Libertarianism is about choices made by people who have both the right and responsibility for doing so. Hence, they argue that the coercive actions of the state are often (or even always) an impediment to the efficient realization individual desires and values.

Heidegger's position may support libertarians and liberals in its over-emphasis on the importance of the individual but 'no one is an Island' and 'it takes a village to raise a child. Aristotle on the other hand opines that man is both social and political animal, that a man who shuns society is either a god or a brute. Yes, Heidegger opted for individualism but it is unavoidable that we must have associations, societies and organizations and abide by their precepts.

Moreover, with Heidegger, we understand that authenticity goes with self autonomy with regard to choices we make. He is of the view that man should make his choices purely on individualistic and relativistic bases. That he should not conform to laid down rules and regulations which characterize mass-existence (inauthenticity). But the question is, does it therefore imply that the thieves, drug pushers, smugglers, terrorists, corrupt politicians and civil servants who infringe upon rules or laws should be ignored since they make their autonomous choices?

If we observe the life of men in our societies, we are struck by two facts. As a rule, every man desires to have his own way, to think and act as he likes, and at the same time everybody cannot have his own way, because he lives in a society. Hence, one man's desires conflicts with those of another. Relations of the individual members of society with one another need regulation by government. The concept of the "person" rather than the "individual" is even better suited for authentic existence. Thus as E. Allen (1967) rightly asserts:

"The individual is seen in isolation or as over against individuals upon whom he makes claims or with whom he concludes agreement; the person is as such in relations with his fellows, bound to whom both by necessity and will, and must find his good in theirs" (p.36) Moreover, what psychologists call an integrated personality qualifies for an authentic mode of existence much more than an "otherless" individual.. It is so because, in our globalised world, we are shaped by others; we also shape them, looking at the world from the perspective of others.

Conclusion

We actually acknowledge that Heidegger's thought has yielded many fresh and penetrating insights into our own human existence. It is just like a restatement of the Socratic dictum "Man know thyself"-Gnothi Seauton. However, we have to remark, that presently, we live in the environment that is deeply connected because of phenomenal globalisation that 
marks our contemporary world. We think that Heidegger has a point in his insistence on individual choice of our existence in line with liberalism. However, despite the gains of individual autonomy, we remain connected to everyone and everything around us. Indeed, the human genome project revealed the full reality of how connected we are; the acknowledgement of the other and the significance of human agency.

Hence, we are destined to fall away from this authentic mode of existence into the world of everyday concern, and it is within this world of concern that we build our lives by the decisions we make and the tasks we undertake every day. The notion of the 'other' and 'otherness, also called 'alterity' are very important in postmodernism. All men and women share common humanity, yet each one has a certain uniqueness and a unique perspective on the world. Yes, individual experience is prized but we cannot be oblivious of the fact that every individual is always involved with others. Here we find ourselves in others and others in ourselves. Therefore, Heidegger's theory of authentic and inauthentic existence cannot stand in the market place of ideas in our globalised world situation. Nevertheless, the worrisome question is, what autonomy remains for individuals in a mass society? This question calls for further research.

\section{References}

Allen, E. L. (1967). Christian Humanism London: Hodder and Stronhton, p. 36.

Anowai, E. (2014). Philosophy: A more Historical Approach, Fab Anie nig Ltd, p. 213.

Arendt, H. (1958). The Human Condition,University of Chicago Press,p.7.

Boaz, D. (1998). Libertarianism: A Primer: Free Press, Pp.22-25.

Corneliu B. (2005). The European Conventionof Human Rights, volume I - (RightsandLiberties, Publishing House AllBeck, Bucharest,), p. 20.

Heidegger, M. (1962).Being and Time, translated by John Macquarrie and Edward Robinson (San Francisco, Harper,) p. 155.

Kierkegaard, S. (1962). The present Age, Alexander Dru (Trans) New York: Harper \& Row,), p.59.

King, M. (1966). Heidegger's Philosophy: A Guide to His Basic Thought (New York: Dell Publishers,) p. 107.

Lawhead, W. F. (2002). The Voyage of Discovery, AHistorical Introduction to Philosophy, $2^{\text {nd }}$ ed; Thomson learning, USA, p. 536.

Murry, R. (1977). Do You Hate the State? The Libertarian Forum, 10(7), July.

Roberts D, E. (1959). Existentialism and Religious Beliefs New York: Oxford University Press, p.151.

Roberts, D. E. (1959). Existentialism and Religious Beliefs (New York: Oxford University Press, p.151.

\section{Copyrights}

Copyright for this article is retained by the author(s), with first publication rights granted to the journal.

This is an open-access article distributed under the terms and conditions of the Creative Commons Attribution license (http://creativecommons.org/licenses/by/4.0/). 